\title{
Kierunki przemian dydaktyki w naukach o bezpieczeństwie
}

\author{
Alternative Directions of Teaching Safety Sciences
}

\section{- Abstrakt •}

Obecne czasy niosą ze sobą ogromny ładunek różnorodnych zdarzeń, wiek XXI jest bowiem wiekiem wielkich przemian i ogromnego postępu w różnych sferach życia człowieka. W związku z postępującymi zagrożeniami społecznymi i cywilizacyjnymi zmniejsza się poczucie bezpieczeństwa wielu środowisk i grup społecznych. Dlatego też rośnie znaczenie edukacji dla bezpieczeństwa, szczególnie w przeciwdziałaniu różnym zagrożeniom. Uświadomienie rodzajów i możliwości zagrożeń, szeroko pojęta profilaktyka oraz racjonalne wychowanie we wszystkich możliwych płaszczyznach życia - powinno mieć swoje główne odbicie w dobrze realizowanej dydaktyce nauk o bezpieczeństwie.

Słowa kluczowe: bezpieczeństwo, nauki o bezpieczeństwie, dydaktyka, edukacja dla bezpieczeństwa

\section{- Abstract •}

Current times carry a huge load of various events because the 21st century is the century of great changes and huge progress in various spheres of human life. The feeling of security in many environments and social groups diminishes due to development of social and civilization threats. This is why safety education is increasingly important in counteracting various threats. Informing about the kinds of threats and their likelihood, widely understood preventive actions, and rational education in all possible spheres of life - ideally all should be part of teaching safety sciences.

Keywords: safety, safety sciences, didactics, safety education

\section{Wstęp}

Nauki o bezpieczeństwie zajmują się w swojej istocie systematycznym rozpatrywaniem problemów życia ludzi i ich bezpieczeństwa. Ich paradygmat występuje wokół problemów istnienia, rozwoju i normalnego funkcjonowania człowieka. 
Ryszard Wróblewski (za: Sienkiewicz, 2010) uznaje, iż nauki o bezpieczeństwie narodowym można wstępnie zdefiniować jako dyscyplinę badawczą zajmującą się badaniem warunków przetrwania i rozwoju społeczeństwa i na tej podstawie projektowaniem systemów bezpieczeństwa w aspekcie zapewnienia pewności istnienia tych warunków.

Centralnym problemem w naukach o bezpieczeństwie jest tworzenie wiedzy w zakresie bezpieczeństwa narodowego, celem zaś jest dostarczanie wiedzy: naukowej - wskazującej prawidłowości występujące w przedmiocie badań, prognostycznej - ukazującej tendencje rozwojowe procesów bezpieczeństwa, oraz praktycznej - przedstawiającej dyrektywy praktycznego działania (wskazującej, jak działać efektywnie).

Zdaniem Stanisława Zajasa (za: Sienkiewicz, 2010) nauki o bezpieczeństwie powinny obejmować przede wszystkim całokształt problematyki bezpieczeństwa w wymiarze pozamilitarnym. Przedmiotem badań tej dyscypliny powinny być współczesne systemy bezpieczeństwa, ich funkcjonowanie na różnych poziomach organizacyjnych (globalnym, państwowym, lokalnym), w których uczestniczą różne służby i instytucje administracji publicznej.

Do nowych poszukiwań badawczych w zakresie bezpieczeństwa i dydaktyki można przyjąć dwa główne źródła inspiracji - przemiany zachodzące we współczesnej nauce i przeobrażenia w praktyce edukacyjnej. Dostrzegając znaczenie ogólnego kontekstu przeobrażeń dydaktyki w naukach o bezpieczeństwie, warto zasygnalizować najpierw ogólne tendencje przemian we współczesnym procesie edukacji, a następnie wskazać na niektóre problemy dotyczące jakości kształcenia. Przyjęcie takiego zakresu odniesienia nie jest podejściem nowym. Idzie tu jednakże o zasygnalizowanie w tych obszarach kilku kwestii, które wydają się ważne (chociaż niekiedy dyskusyjne) w poszukiwaniach współczesnych podstaw badań w zakresie dydaktyki bezpieczeństwa.

W świecie niepewności, pełnym różnorodnych zagrożeń, to właśnie dydaktyka jest postrzegana jako swoista szansa zapewniania jednostkom ludzkim i szeroko rozumianym społecznościom harmonijnego rozwoju intelektualnego, moralnego, emocjonalnego, kulturowego i związanego z działalnością praktyczną. Kształcenie człowieka $\mathrm{w}$ zakresie bezpieczeństwa powinno również uwrażliwiać na istotne aspekty postmodernistycznego świata, a zwłaszcza podejmować próbę odpowiedzi na odwiecznie zadawane pytanie: „co robić, a czego nie robić?’'(Kotarbiński, 1976).

Poszukiwanie coraz to efektywniejszych i skuteczniejszych sposobów kształcenia wiąże się nie tylko z rozwojem nowych teorii, lecz również z doskonaleniem praktyki. Poszukiwanie optymalnych rozwiązań, wdrażanie innowacji dydaktycz- 
nych, weryfikowanie różnych koncepcji procesu dydaktycznego to zadania stojące przed nauczycielami, które wymusza szybko zmieniająca się rzeczywistość.

Aby w miarę trafnie wskazać prawdopodobne tendencje rozwoju dydaktyki w naukach o bezpieczeństwie, trzeba również wyróżnić istniejące modele i paradygmaty kształcenia. W rozwoju teoretycznych podstaw dydaktyki należy wykorzystać dotychczasowy dorobek, szczególnie w zakresie kształcenia ustawicznego i wszechstronnego, koncepcji poznawczych i psychologicznych. Dążenie do podniesienia efektów procesu kształcenia wiąże się ściśle z rozwojem teorii procesu kształcenia. Na proces ten składa się bardzo wiele zmiennych wchodzących ze sobą w różnorakie interakcje i powiązania. Istotne jest więc zapewnienie systemowego podejścia do tej problematyki. Konsekwencją ujęcia systemowego jest rozpatrywanie każdego elementu systemu zawsze jako składnika złożonej całości. Podejście systemowe powinno prowadzić do podniesienia efektywności procesu kształcenia.

Celem artykułu jest wskazanie zasadniczych kierunków przemian dydaktyki nauk o bezpieczeństwie szczególnie w warstwie aksjologiczno-teleologicznej oraz $\mathrm{w}$ warstwie procesowej.

Głównymi źródłami wiedzy wykorzystanej przy opracowaniu niniejszego artykułu były treści pochodzące z dydaktyki ogólnej i dydaktyki bezpieczeństwa, psychologii zagrożeń, aksjologii bezpieczeństwa, pedeutologii oraz teorii kształcenia.

Artykuł składa się z czterech zasadniczych części: wprowadzenia, opisu najważniejszych modeli i paradygmatów dydaktyki, związków dydaktyki nauk o bezpieczeństwie z procesem kształcenia oraz podsumowania.

\section{Modele uprawiania dydaktyki w naukach o bezpieczeństwie}

Aktualną tendencją w dydaktyce jest jej uprawianie jako dyscypliny empiryczno-analitycznej i jako dyscypliny humanistycznej. Dwa modele, obiektywistyczny i interpretatywny, nie mogą być traktowane opozycyjnie, są równoprawne, niezbędne i komplementarne w rozwoju dydaktyki jako nauki o bezpieczeństwie, są użyteczne poznawczo, gdyż niektóre zjawiska dydaktyczne wymagają stosowania obserwacji, pomiaru, inne wymagają podejścia jakościowego, humanistycznego. Model humanistyczny, który coraz częściej jest stosowany i zalecany w badaniach dydaktycznych, zakłada, że natura zjawisk dydaktycznych jest niepowtarzalna, wymaga zrozumienia i interpretacji. Zastosowanie metod badań jakościowych 
wiąże się z podkreśleniem znaczenia intuicji i empatii, z eksponowaniem podmiotowości osób uczących się i nauczycieli, partnerstwem, dialogiem dydaktycznym.

Wyraźną potrzebą w rozwoju dydaktyki bezpieczeństwa jest odchodzenie od jednego paradygmatu, a poszukiwanie różnych modeli rozumienia i uprawiania kształcenia. Rysujący się trend wynika z rozwoju nauk o bezpieczeństwie, z którymi związana jest dydaktyka. Wyraźnie widoczny jest związek dydaktyki z psychologią, a w szczególności z teoriami rozwoju osobowości człowieka czy też psychologicznymi teoriami uczenia się. Eksponowanie psychologii poznawczej w interpretacji rozwoju człowieka i analizie procesu uczenia się z perspektywy edukacji dla bezpieczeństwa staje się podstawą do innego rozumienia i uprawiania kształcenia. Osobę uczącą się postrzega się jako sprawcę swoich działań, jako istotę aktywną, działającą pod wpływem potrzeby samorealizacji, według systemu uznanych wartości, zgodnie z przyjętym planem czy orientacją życiową. Proces uczenia się jako proces poznawania rzeczywistości i samego siebie przez aktywnego studenta (ucznia) jest analizowany w świetle różnych dyscyplin naukowych, a wykorzystanie najnowszych osiągnięć w tym zakresie pozwala na inne podejście do procesu $\mathrm{i}$ inne jego traktowanie oraz inną realizację. Zwraca się uwagę na proces uczenia się z perspektywy heutagogicznej, według której proces jest analizowany z punktu widzenia osoby uczącej się i jego doświadczeń. Jest to przeniesienie akcentu z wykładowcy, który często był inspiratorem procesu uczenia się, na studenta (ucznia), czyli osobę świadomą swoich dotychczasowych doświadczeń, potrzeb i aspiracji. Według tej koncepcji uczący się człowiek w ciągu swojego życia sam odkrywa różne idee i nie musi być karmiony mądrością innych.

Możliwości, jakie stwarza epoka cyfrowa, stały się podstawą nowej teorii nauczania - konektywizmu, której autorami są kanadyjscy naukowcy George Siemens i Stephen Downes. Podstawą tej teorii jest znaczenie, jakie przypisuje się oddziaływaniu technologii na nasze życie, na sposób komunikowania się, a także na to, jak się uczymy. Charakterystyczną cechą konektywizmu jest łączenie się z zasobami informacji i gromadzenie wiedzy w urządzeniach. Ludzka wiedza nie musi być cała w głowie, wiedza, którą posiadamy, może znajdować się w urządzeniach poza nami i dopiero połączenie się z tymi zasobami uruchamia proces uczenia się, nie do końca znajdujący się pod kontrolą uczącego się czy nauczającego. Inną cechą jest tworzenie i utrzymywanie połączeń między różnymi węzłami w Sieci, tj. informacja, dane, uczucia, obrazy itp. Według konektywizmu cenione jest krytyczne myślenie, charakterystyczne dla pedagogiki krytycznej, stanowiące podwaliny pod szkołę myślenia, eliminując dzisiejszą szkołę „wiedzową”. Istotne jest wybieranie przez osoby uczące się treści uczenia się i samodzielne podejmowanie decyzji na podstawie określonego, nieustannie zmieniającego się zasobu informa- 
cji. Najważniejszą kompetencją jest rozróżnianie, co jest istotne, a co nie jest. Kluczem prowadzącym do poszukiwanego zasobu wiedzy, metazasadą efektywnego uczenia się staje się „wiedzieć gdzie” (know-where), zamiast „wiedzieć jak” (know-how) czy „wiedzieć co" (know-what; Siemens, 2005).

Thomas Samuel Kuhn (1985) twierdzi, że „czymkolwiek byłyby paradygmaty, są one własnością każdej naukowej społeczności, włącznie ze szkołami tak zwanego okresu przed-paradygmatycznego". Problem ten jest częścią refleksji Wolfganga Welscha nad istotą nowoczesności XX wieku i obligatoryjnością pluralizmu przejawiającego się w uznaniu i praktykowaniu wielości (Welsch, 1997). Czesław Kupisiewicz (2009) definiuje paradygmat jako wzór, model: „Potocznie - typowy przykład lub model do wzorowania się lub wykorzystania; w znaczeniu filozoficznym - powszechnie uznane osiągnięcie naukowe, dostarczające modelowych rozwiązań w określonej dziedzinie nauki, a także w dziedzinach pokrewnych". Dydaktyka w naukach o bezpieczeństwie, jako teoria kształcenia i samokształcenia, jest współcześnie przeniknięta wielością modeli myślenia o skutecznym nauczaniu uczenia się, a w jej strukturze konkurują różne paradygmaty, często bardziej potwierdzające istnienie społeczeństwa ryzyka i zagrożenia.

Problem funkcjonowania paradygmatów edukacyjnych w dydaktyce wyjątkowo trafnie interpretuje Joanna Rutkowiak (za: Klus-Stańska, Łojko, Hurło, 2009), wskazując na istnienie pewnych wyodrębnionych podzbiorów przekonań tkwiących w paradygmatach, umożliwiających wyodrębnienie jako szczególnie obecnie znaczących pomysłów, koncepcji, sposobów i ukierunkowań kształcenia. Są to: „paradygmat nauczania podającego i poszukującego, odtwórczo-transmisyjnego i twórczego, dydaktykę nauczania - uczenia się, dydaktykę scjentystyczną, jako techniczno-instrumentalną i humanistyczną, nauczanie eksploracyjne i w «wersji ostatecznej», dydaktykę obiektywizmu i subiektywizmu, paradygmat kształcenia pozytywnego i krytycznego, edukacyjną "teorię wpływu» - jako przekazu i «teorię rozwoju", przedstawianą w formule konstruktywistycznej".

Optymalnym rozwiązaniem problemu istnienia i funkcjonowania wieloparadygmatyczności również w dydaktyce bezpieczeństwa jest, zdaniem Joanny Rutkowiak, wykorzystanie projektu przekładów paradygmatycznych, zakładających m.in. tworzenie płaszczyzny współgrania paradygmatów rozumianych jako „ciągłe problematyzowanie/upewnianie się, tworzące ruch myśli, sprzyjający ogarnianiu komplikacji stanu realnej wieloparadygmatyczności” (za: Klus-Stańska, Łojko, Hurło, 2009). Z kolei Stanisław Dylak (za: Klus-Stańska, Łojko, Hurło, 2009) wyróżnia dwa podstawowe, odległe od siebie, choć mogące współistnieć paradygmaty także w dydaktyce nauk o bezpieczeństwie: „Pierwszy z nich wynika z traktowania wiedzy jako produktu i związanej z tym konieczności jej upowszechnia- 
nia. Drugi to ujmowanie wiedzy jako procesu, głęboko osadzonego w osobistych odniesieniach, emocjach i doświadczeniach. Oba te ujęcia istnieją równolegle od dawna - ten pierwszy głównie w instytucjach formalnego kształcenia, ten drugi w edukacji nieformalnej”.

Wymienione paradygmaty stanowią przykład dychotomicznego postrzegania dydaktyki jako teorii i praktyki, raz tkwiącej głęboko w idei nauczania podającego, zwanego niezbyt słusznie tradycyjnym, w którym następuje udostępnianie osobie uczącej się gotowej do zapamiętani wiedzy (wiadomości), a drugi raz otwartej na rozbudzanie ciekawości i rozwijanie jej aktywności poznawczej, zainteresowań, samodzielności i twórczości, aż do samorealizacji. Stąd już blisko do paradygmatu rozróżniania metod podających (werbalnych) i aktywizujących; ogniw dydaktycznych nauczania podającego i nauczania problemowego (poszukującego); egzaminów (sprawdzania osiągnięć) według podejścia behawiorystycznego czyniącego przedmiotem oceny wiedzę faktograficzną i podejścia konstruktywistycznego skupiającego się na ocenie operowania wiedzą w kontekście realnego życia (Gołębniak, za: Kwieciński, Śliwerski, 2003).

W dość uproszczonym ujęciu paradygmat to pewnik, którego nikt nie podważa. Otóż w dydaktyce nauk o bezpieczeństwie i w szeroko rozumianej edukacji takie rozumienie paradygmatu jest bardzo trudne do zaakceptowania. Wystarczy przywołać tok rozumowania Czesław Kupisiewicza (1985), który konstruując paradygmaty reform oświatowych, zaproponował następujący ich podział:

- „wymierzone przeciwko obecnej szkole (społeczeństwo bez szkoły),

- usiłujące ją zastąpić za pomocą alternatywnych rozwiązań edukacyjnych (szkoła alternatywna),

- takie, które zmierzają do zachowania zasadniczej konstrukcji strukturalno-organizacyjnej szkoły istniejącej, konwencjonalnej, przy równoczesnym ustawicznym doskonaleniu realizowanych przez nią celów i treści, a także stosowanych metod, form organizacyjnych oraz środków pracy dydaktyczno-wychowawczej (szkoła ustawicznie doskonalona)".

Pożądanym kierunkiem zmian $\mathrm{w}$ dydaktyce nauk o bezpieczeństwie jest kształtowanie paradygmatu edukacji podmiotowej, według którego osoba ucząca się staje się podmiotem kształcenia. Organizowanie edukacji wyznaczają nie potrzeby państwa, a aspiracje, potrzeby życiowe i rozwój jednostek oraz grup społecznych. Kształtowanie aktywności i poczucia podmiotowości zapewnia współudział uczących się w organizowaniu zajęć dydaktycznych, ich planowaniu, przygotowywaniu, prowadzeniu i ocenianiu. Zaangażowanie ich w planowanie zajęć prowadzi do odczucia, że nie są oni biernymi odbiorcami propozycji i ofert stawianych przez nauczyciela, ale są twórcami zadań, które pobudzają do aktywności, bo 
uznają je za własne. Działania są zdecydowanie bardziej efektywne, gdy człowiek odczuwa możliwość decydowania o sposobie postępowania, w którym wybór jest wynikiem jego własnej decyzji.

Bardzo istotny wpływ na kształtowanie się podmiotowości i wielopodmiotowości mają emocje. Są one ściśle powiązane z uczuciami, motywacją i działaniami jednostki ludzkiej. Emocje bardzo często definiuje się jako reakcje na przyjemne lub przykre wydarzenia bądź okoliczności. Skoro emocje powstają na bazie relacji społecznych, to ich znajomość i „praca z nimi” sprzyjają skutecznemu kształtowaniu się umiejętności ich wyrażania (Stein, Trabasso, Liwag, za: Lewis, Haviland-Jones, 2005).

W refleksji nad koncepcją przemian dydaktyki nauk o bezpieczeństwie szczególne miejsce jako podmiotu działań przypada nauczycielowi - pisze Henryka Kwiatkowska (2008) - zwraca uwagę na to, że „wraz ze wzrostem indywidualizmu człowieka obserwuje się proces coraz wyraźniejszego podziału ludzi na funkcjonujących podmiotowo i funkcjonujących przedmiotowo. (...) Szkoła funkcjonująca według standardu podmiotowego kształci ludzi niezależnych, autonomicznych, podmiotowych, natomiast szkoła pracująca według standardu przedmiotowego - ludzi zależnych, podporządkowanych, uległych”.

Zaprezentowany pogląd ma niezwykle istotne znaczenie nie tylko dla zrozumienia i zasadności eksponowania paradygmatu podmiotowości w dydaktyce nauk o bezpieczeństwie, ale również dla wyjaśnienia potrzeby rozróżniania modeli dydaktyki behawiorystycznej i konstruktywistycznej. Z pewnością konceptualizacja złożonych procesów edukacyjnych i warunków, w jakich one przebiegają, wymaga wielu zmian w teorii kształcenia (w dydaktyce ogólnej) i wprowadzenia nowych rozwiązań praktycznych (Klus-Stańska, 2010).

W tej sytuacji nawet dobrze wykształcony nauczyciel o wyrazistej podmiotowości i tożsamości osiągniętej, potwierdzającej dogłębne rozpoznanie siebie samego, swoich możliwości i warunków działania, stosuje styl instrukcyjny, w którym „poleca, określa zakres pracy, tempo, kontroluje pracę, oczekuje jednoznacznego wyniku, często opiera całą aktywność na wypełnianiu «kart pracy», a więc relacje osoby uczącej się ze światem są organizowane przez nauczyciela, a często jest on tylko biernym wykonawcą i odtwórcą. Sprzyja to rozwojowi postaw pasywnych, biernych wobec zadań, gdzie osoby uczące się oczekują na kierowanie zewnętrzne, a brak inicjatywy i podporządkowanie należą do codziennych doświadczeń" (Klus-Stańska, 2010).

Nauczyciele oczywiście coraz częściej wykorzystują inne style nauczania, umożliwiające odchodzenie od instrukcyjności i formalnego, pełnego dystansu kontaktowania się z osobami uczącymi się, takie jak: styl ramowy (zindywidu- 
alizowany), styl negocjacyjny i styl delegujący (oparty na uznaniu uczących się jako istot aktywnych, o wysokiej gotowości poznawczej i podmiotowej), ale krytyka rzeczywistości szkolnej nie słabnie, a nawet się nasila. Na podstawie literatury można stwierdzić, że tworzenie klimatu społecznego, psychologicznego i pedagogicznego w polskich szkołach sprzyjającego rozwojowi podmiotowości ucznia, jego samodzielności, aktywności i konsekwentnemu dążeniu do samorealizacji, zależy głównie od osoby nauczyciela i jego kompetencji osobowych oraz profesjonalnych.

Z kolei Jerome Seymour Bruner (1974) dostrzega potrzebę zwracania większej uwagi na wspólnotę nauczających i uczących się. Wspólnota ta jest pochodną swobodnej wymiany myśli, dyskusji i wzajemności, która nie musi oznaczać, że wszyscy uczą się tego samego, program jest z góry ustalony, ciekawość będąca prototypem motywacji wewnętrznej ulega ograniczeniu. Podobnie określa swój stosunek do szkoły George Kerschensteiner, twierdząc, że punktem wyjścia w edukacji nie może być treść kształcenia, lecz sam uczeń, jego uzdolnienia, cechy charakteru, podmiotowość i poczucie wspólnoty (Kerschensteiner, za: Molak, 1968).

Wśród wielu paradygmatów dydaktyki nauk o bezpieczeństwie należy zwrócić uwagę na podejście humanistyczne do kształcenia. Przedstawiciele szkoły humanistycznej (Carl Rogers, Abraham Maslow, Gordon Allport) uważają, że najważniejsze w procesie edukacji jest zaspokajanie potrzeb poszczególnych osób uczących się, stworzenie możliwości rozwijania ich własnego potencjału. Zdaniem autorów, należy pozwolić uczącym się, aby sami kierowali swoim rozwojem, brali odpowiedzialność za swoją naukę i rozwój. Rolą nauczyciela staje się zapewnienie uczniom poczucia bezpieczeństwa, akceptacji i wywołania pozytywnej motywacji do osiągania sukcesu.

$\mathrm{Na}$ zakończenie tej skromnej analizy istoty myślenia o paradygmatach $\mathrm{w}$ dydaktyce nauk o bezpieczeństwie należy podkreślić z jednej strony ich heterogeniczność i osadzenie - jak twierdzi Wolfgang Welsch (1997) - w nieusuwalnym pluralizmie ponowoczesnego społeczeństwa, a z drugiej utrzymywanie się dychotomicznego podziału na transmisyjno-reproduktywną doktrynę kształcenia typową dla szkoły tradycyjnej i doktrynę generatywną, eksponującą podmiotowy charakter roli osób uczących się i stymulującą działania nauczyciela wspomagającego procesy uczenia się jego wychowanków.

Opowiadając się w pełni za potrzebą szerszego doceniania tych paradygmatów (modeli, wzorców) współczesnej dydaktyki nauk o bezpieczeństwie, które koncentrują się na idei szkoły humanistycznej, zaspokajającej intelektualne (poznawcze), emocjonalne, kulturowe i praktyczne potrzeby uczących się oraz nauczycieli, zasadne jest skupienie się na tym właśnie obszarze refleksji dydaktyczno-wycho- 
wawczej znajdującej swoje źródła w coraz szerzej upowszechnianej idei budowania dobrej szkoły, zapewniającej warunki bycia podmiotem wszystkim uczestnikom procesu kształcenia.

\section{Związki dydaktyki nauk o bezpieczeństwie $\mathrm{z}$ procesem kształcenia}

Tadeusz Kotarbiński (1957) definiuje „proces” jako: „(...) zdarzenie będące zmianą zmierzającą w określonym kierunku za przyczyną jakiegoś wskazanego czynnika”. Leszek Krzyżanowski (1985) „proces” rozumie jako: „(...) jakikolwiek ciąg (pasmo, łańcuch) zmian, zachodzących w bezpośrednio następujących po sobie lub zachodzących na siebie chwilach, intencjonalnie wyróżnionych pod jakimś względem jako pewna całość". Można przyjmować różne kryteria, według których wyróżniane są ciągi zmian jako procesy.

Należy zatem przyjąć, że przez „proces” rozumie się kolejne zmiany określonego stanu, w którym zachodzą ścisłe związki regularnie występujących po sobie stadiów rozwoju, co w konsekwencji prowadzi do założonych zmian w osobowości uczących się i w ich działaniu. Odnosząc to pojęcie do dydaktyki nauk o bezpieczeństwie, można stwierdzić, że „proces” oznacza ciąg powiązanych ze sobą i wzajemnie od siebie zależnych czynności, zjawisk i zamierzeń, w rezultacie których studiujący przyswajają sobie określony zasób wiadomości, umiejętności i nawyków z zakresu bezpieczeństwa oraz rozwijają swoje zainteresowania w zakresie tej problematyki, kształtują odpowiednie postawy, poglądy i przekonania, czyli przekształcają i wzbogacają swoją osobowość.

Proces kształcenia, jako ciąg wzajemnie zintegrowanych czynności nauczyciela i osób uczących się, zmierzających do przyjętych celów kształcenia, jest jednym z najważniejszych elementów systemu dydaktycznego. Każde kształcenie powinno być ukierunkowane na cele, które są jakby elementem nadrzędnym w stosunku do pozostałych. Ustalenie i sformułowanie celów kształcenia jest istotnym warunkiem trafnego projektowania dydaktycznego. Cele, z kolei, warunkują dobór odpowiednich treści kształcenia, które stanowią tworzywo materialne warunkujące osiągnięcie celów. Realizacja treści kształcenia odbywa się za pomocą odpowiednich sposobów kierowania procesem dydaktycznym, czyli metod, form i środków kształcenia.

W dobie kryzysu edukacyjnego istotne jest poszukiwanie nowych celów kształcenia, a wśród nich ważne wydają się takie, jak kształcenie postawy twórczej, wychowanie do twórczej pracy, do zmiany społecznej, do samorozwoju. Dążenie 
do celów kształcenia związanych z wysiłkiem intelektualnym, z przetwarzaniem i wytwarzaniem wiedzy, z poszukiwaniem rozwiązań alternatywnych jest istotnym warunkiem rozwijania aktywności twórczej osób uczących się. Wartościowymi celami kształcenia są te, które wiążą się z odkrywaniem, wyjaśnianiem i interpretowaniem zjawisk i procesów, wartościowaniem, diagnozowaniem i weryfikowaniem różnorodnych hipotez.

Cele w dydaktyce nauk o bezpieczeństwie spełniają wiele funkcji i zadań. Głównie są to funkcje koordynacyjna i organizacyjna działalności wszelkich instytucji, kształtujących właściwe postawy i wartości na rzecz bezpieczeństwa, gdyż określają zadania i kierunki ich działalności, czemu należy podporządkować wszelkie formy aktywności edukacyjnej. Ponadto cele te mogą pełnić też inne funkcje, między innymi:

- behawioralną - ukierunkowanie aktywności uczestników procesu kształcenia. Nie determinują zachowania, wskazują na kierunek działania,

- emocjonalną - zapewnianie kryteriów oceny wyników działania. Realizacja celów daje poczucie sukcesu. Nieosiągnięcie ich to zarzewie porażki, rozczarowanie i zagrożenie niepowodzeniem,

- orientacyjną - dostarcza informacji dotyczących zajmowanego przez słuchacza miejsca w procesie kształcenia,

- społeczną (kulturową) - wskazuje na więzi kulturowe uczestników procesu kształcenia, ułatwia komunikację między nimi,

- sensotwórczo-podmiotową - wykazuje, że cele nadają życiu ucznia sens. Cele i sens życia są ze sobą ściśle powiązane (Zalewski, 1991; Gałdowa, 1992).

Ogólnym zadaniem realizacji dydaktyki nauk o bezpieczeństwie jest przeciwdziałanie zagrożeniom w czasie pokoju oraz przygotowanie dzieci i młodzieży do rozpoznawania zagrożeń i radzenia sobie z niebezpieczeństwami, jakie niesie codzienne życie (Zduniak, Kryłowicz, 2004).

Formułowanie jedynie celów ogólnych w praktyce kształcenia z zakresu bezpieczeństwa jest mało użyteczne. Ich wadą jest przede wszystkim „(...) nieokreśloność, wieloznaczność, idealizacyjny charakter i nadmierna deklaratywność" (Stępień, Wroński, 1999). Tak sformułowane cele są mało przydatne dla praktyki edukacyjnej. Trudno je bowiem przełożyć na konkretne zadania, a jeszcze trudniej sprawdzić stopień ich osiągnięcia w działalności dydaktyczno-wychowawczej. Dlatego też konieczne jest przedstawianie celów możliwie jak najszczegółowiej, co wbrew pozorom nie jest wcale czynnością ani prostą, ani łatwą. Zabieg polegający na zamianie celów ogólnych na cele operacyjne nazywa się operacjonalizacją celów (Niemierko, 1997; Żegnałek, 2005). Operacjonalizacja celów ogólnych powodu- 
je ich: sprecyzowanie, uszczegółowienie, konkretyzację, upodmiotowienie osiągającego cel. Dzięki temu zabiegowi cele w dydaktyce nauk o bezpieczeństwie stają się jasne i zrozumiałe dla obydwu podmiotów procesu kształcenia, co ma ogromne znaczenie dla jego skuteczności. Niejasny lub tylko pozornie zrozumiany przez uczących się, a także przez nauczycieli cel to pewna droga do niepowodzeń szkolnych (Andrukowicz, za: Denek, Bereźnicki, Świrko-Pilipczuk, 2000).

W trakcie projektowania przez nauczyciela własnego systemu kształcenia szczególne miejsce zajmuje problematyka taksonomizacji celów kształcenia. Poszukiwania kryteriów wyboru taksonomii celów pozwala na rozszerzenie sfery poznawczej wraz ze sferą emocjonalną i psychomotoryczną, co niewątpliwie wpływa na zwiększenie twórczej aktywności intelektualnej osób uczących się.

Na gruncie dydaktyki polskiej największy wkład do teorii i praktyki w zakresie taksonomizacji celów kształcenia wniósł Bolesław Niemierko (1975). W książce $A B C$ testów osiagnięć szkolnych przedstawił on własną taksonomię, która bywa nazywana taksonomią $\mathrm{ABC}$. Obejmuje ona dwa poziomy celów (wiadomości i umiejętności), z których każdy posiada po dwie kategorie celów. Ma ona charakter ponadprzedmiotowy, ale dotyczy tylko dziedziny poznawczej. Zaowocowała jednak wieloma taksonomiami przedmiotowymi. Może być również wykorzystana do opracowania taksonomii celów edukacji dla bezpieczeństwa. Podobnie mogą być wykorzystane taksonomie celów w dziedzinach poznawczej, emocjonalnej i psychomotorycznej (działania), jak też i inne taksonomie.

W taksonomii celów kształcenia z zakresu dydaktyki nauk o bezpieczeństwie należy uwzględniać fakt, że większość działań, do których przygotowuje się uczestników edukacji, ma charakter zespołowy (grupowy) wymagający współpracy i współdziałania. Dlatego cele i zadania dydaktyczne powinny być ukierunkowane na kształtowanie wysokiego poziomu świadomości obronnej oraz kompetencji w zakresie działań obronnych całego społeczeństwa (Żegnałek, 2005).

Istotną kwestią w dydaktyce nauk o bezpieczeństwie jest dobór i wykorzystanie treści kształcenia. Treści te powinny być dostosowane do celów i efektów kształcenia, potrzeb społecznych, rodzaju i poziomu edukacji oraz możliwości intelektualnych uczących się. Analiza programu nauczania (sylabusów) z zakresu dydaktyki nauk o bezpieczeństwie dowodzi, że konieczna staje się taka ich orientacja, aby lepiej służyły adaptacji młodzieży do życia w społeczeństwie: ryzyka, konsumpcji, spektakli, wiedzy. Można to osiągnąć poprzez odpowiedni dobór treści nauczania i uczenia się. W tym celu wydziela się główne, istotne ich człony, niezbędne dla rozwiązania podstawowych zadań. Włącza się do nich sekwencje o charakterze „co należy znać i umieć”. Uwzględnia się wymogi korelacji między tematami wewnątrz przedmiotu nauczania oraz w ramach współdziałających ze 
sobą innych przedmiotów. Przy doborze i układzie treści nauczania i uczenia się na uwagę zasługuje ten kierunek poszukiwań, który nazywa się ontodydaktyką. Zapewnia ona uzyskanie takiego kształtu przedmiotu nauczania, który pozostaje w zgodzie ze strukturalnym, hierarchicznym i zintegrowanym charakterem wiedzy (Denek, Meller, 1992).

Zagadnienie różnicowania treści kształcenia na ogół nie budzi wątpliwości. W związku z tym rodzi się pytanie, na ile efektywne są indywidualne programy studiów, w jakim kierunku winny zmierzać przemiany treści kształcenia? Jednoznacznej odpowiedzi nie dadzą rozważania teoretyczne. Wiele mogą uczynić nauczyciele tworzący programy autorskie lub realizujący nowe koncepcje programowe.

Przebieg procesu dydaktycznego winien być zróżnicowany w zależności od celów i treści kształcenia, jak też od doboru odpowiednich metod w danej sytuacji dydaktycznej. Złożony i wieloczynnościowy charakter kształcenia w szkolnictwie wymaga stosowania bogatego repertuaru metod pracy nauczyciela i uczących się. Istotną cechą nowoczesnego pojmowania metod kształcenia jest ich wpływ na wzbudzanie wszechstronnej aktywności uczniów i studentów, na rozwój twórczego myślenia i działania. Różnorodność stosowanych metod kształcenia to potencjalne bogactwo inspirowanych procesów osobotwórczych. Stąd też wielostronności kształcenia sprzyjać winny, oprócz tradycyjnych metod, niekonwencjonalne metody kształcenia, do których zaliczamy:

- gry dydaktyczne (sytuacyjne, symulacyjne, rozstrzygnięć sądowych),

- metody dialogowe (dyskusja panelowa, burza mózgów, sesja wątpliwości),

- metody twórczego myślenia i działania.

W dydaktyce nauk o bezpieczeństwie w większym stopniu należy eksponować potrzebę rozwijania twórczego myślenia z wykorzystaniem różnych technik twórczego rozwiązywania problemów. Techniki te rozwijają wrażliwość na problemy, ćwiczą giętkość i płynność myślenia, stwarzają okazję do poszukiwania oryginalnych, twórczych rozwiązań, kształcą umiejętność podejmowania racjonalnych decyzji i umiejętność uczenia się innowacyjnego. Innowacyjne uczenie się przygotowuje osoby uczące się do stosowania takich technik jak prognozowanie, symulacja, tworzenie scenariuszy i modeli.

Ważnym etapem w optymalizacji procesu kształcenia w dydaktyce nauk o bezpieczeństwie są: poznawanie, kontrola, analiza i ocena postępów, które czynią jego uczestnicy. Kwestiami tymi - określanymi jako „kwalifikowanie wiedzy” - zajmuje się dział dydaktyki ogólnej nazywany docymologią. Punktem odniesienia dla kwalifikowania wiedzy są cele kształcenia. Kwalifikowanie sprowadza się tu do ustalenia zależności między wynikami kształcenia a stawianymi celami, wyrażanymi w kategoriach zadań. W trakcie ustalania tych zależności warto posłużyć 
się - poza tradycyjną kontrolą i oceną postępów w nauce - takimi ogniwami nowoczesnego kwalifikowania wiedzy, jak: dydaktyczny wskaźnik poziomu wiedzy (kryterium Q), testy dydaktyczne, kryteria i normy ocen, kontrola programowana, kontrola standaryzowana oraz weryfikacja postępów w nauce z udziałem probabilistycznych metod ich poznawania.

O jakości i efektywności procesu kształcenia w dydaktyce nauk o bezpieczeństwie, bez względu na szczebel edukacyjny, decydują też inne czynniki. Nie ulega jednak wątpliwości, iż jednym z nich jest charakter relacji nauczyciela ze studentami (uczniami). Szczególnie podkreśla się w literaturze potrzebę oparcia tych stosunków na dialogu i zapewnieniu warunków dla podmiotowego funkcjonowania obu stron.

Podsumowując, można stwierdzić, że kierunki przemian w dydaktyce nauk o bezpieczeństwie nie tylko powinny wynikać z aksjologicznych i teleologicznych aspektów bezpieczeństwa, uwarunkowań procesu kształcenia, ale powinny także obejmować szeroki zakres programowy przedmiotów ogólnokształcących, z uwzględnieniem poszczególnych etapów (poziomów) i rodzajów szkół oraz uczelni.

Szczególnej uwadze należy poddać następujące grupy zagadnień:

- popularyzację służb mundurowych jako jednego z elementów bezpieczeństwa kraju,

- charakterystykę zagrożeń powodowanych przez współczesną cywilizację i ochronę przed tymi zagrożeniami,

- ratownictwo medyczno-sanitarne, ze szczególnym uwzględnieniem pierwszej pomocy przedmedycznej, oraz kierowanie zespołami Wojsk Obrony Terytorialnej,

- zasady zachowania się społeczeństwa w przypadku ewentualnego zagrożenia wewnętrznego (terroryzmu),

- wyzwolenie i kształtowanie naturalnych, dotyczących bezpieczeństwa, prospołecznych działań człowieka w jego środowisku.

W dydaktyce nauk o bezpieczeństwie konieczne są zmiany, które podążają w kierunku:

- rozwoju różnych teorii kształcenia;

- doskonalenia praktyki pedeutologicznej;

- poszukiwania optymalnych rozwiązań w różnych sytuacjach dydaktycznych;

- wdrażania innowacji dydaktycznych;

- weryfikowania stosowanych koncepcji procesu dydaktycznego;

- poszukiwania dalszych kryteriów wyboru taksonomii celów kształcenia; 
- wprowadzania eksperymentalnych programów nauczania i programów autorskich;

- konstruowania wiedzy przez samych uczących się;

- wykorzystywania wiedzy, nabywania kompetencji potrzebnych w epoce cyfrowej;

- wyznaczania celów przez uczestników procesu edukacyjnego;

- wiązania treści z życiem, współczesnymi problemami i zagrożeniami (w zakresie treści);

- wprowadzania metod aktywizujących, wdrażających do samodzielnego myślenia i działania;

- stosowania nowoczesnych technologii informacyjno-komunikacyjnych;

- podmiotowego traktowania uczestników procesu kształcenia;

- dialogu uczestników procesu edukacyjnego.

Pragnę zwrócić uwagę, iż zmiany w dydaktyce nauk o bezpieczeństwie powinny odpowiadać nie tylko wymaganiom współczesnej cywilizacji, gdzie wiele pojęć, procesów dydaktycznych wymaga nowego odczytania, redefinicji, nowego interpretowania, ale też odpowiadać współczesnym zagrożeniom społecznym, kulturowym czy też osobowościowym człowieka.

\section{Bibliografia:}

Andrukowicz, W. (2000). Projekt celów kształcenia integralnego. Za: K. Denek, F. Bereźnicki, J. Świrko-Pilipczuk (red.), Przemiany dydaktyki na progu XXI wieku. Szczecin: Uniwersytet Szczeciński.

Bruner, J.S. (1974). W poszukiwaniu teorii nauczania. Warszawa: Państwowy Instytut Wydawniczy.

Denek, K., Meller, R. (1992). Treści kształcenia w przyszłościowym modelu edukacji. Ruch Pedagogiczny, 5/6.

Dylak, S. (2009). Koniec „nauczania” czy nowy paradygmat dydaktyczny. Za: D. KlusStańska, M. Łojko, L. Hurło (red.), Paradygmaty wspótczesnej dydaktyki. Kraków: Oficyna Wydawnicza Impuls.

Gałdowa, A. (1992). Powszechność i wyjątek. Rozwój osobowości człowieka dorosłego. Kraków: Platan.

Gołębniak, B.D. (2003). Egzaminy i ocenianie szkolne. Za: Z. Kwieciński, B. Śliwerski (red.), Pedagogika. Podręcznik akademicki, t. 2. Warszawa: PWN.

Klus-Stańska, D. (2010). Dydaktyka wobec chaosu pojęć i zdarzeń. Warszawa: Wydawnictwo Akademickie „Żak”.

Kotarbiński, T. (1957). O pojęciu metody. Wybór pism, t. I. Warszawa: Państwowe Wydawnictwo Naukowe.

Krzyżanowski, L. (1985). Podstawy nauki zarządzania. Warszawa: PWN. 
Kuhn, T.S. (1985). Dwa bieguny. Tradycja i nowatorstwo w badaniach naukowych. Warszawa: Państwowy Instytut Wydawniczy.

Kupisiewicz, Cz. (1985). Paradygmaty i wizje reform oświatowych. Warszawa: PWN.

Kupisiewicz, Cz., Kupisiewicz, M. (2009). Stownik pedagogiczny. Warszawa: PWN.

Kwiatkowska, H. (2008). Pedeutologia. Warszawa: Wydawnictwo Akademickie i Profesjonalne.

Molak, A. (1968). Szkoła pracy Kerschensteinera. Warszawa: PWN.

Niemierko, B. (1975). ABC testów osiagnięć szkolnych. Warszawa: WSiP.

Niemierko, B. (1997). Między ocena szkolna a dydaktyka. Bliżej dydaktyki. Warszawa: WSiP.

Rutkowiak, J. (2009). Wielość paradygmatów dydaktyki a wspólny mianownik realności życia. Ku pytaniom o przykłady międzyparadygmatyczne. Za: D. Klus-Stańska, M. Łojko, L. Hurło (red.), Paradygmaty wspótczesne dydaktyki. Kraków: Oficyna Wydawnicza Impuls.

Stein, N.L., Trabasso, T., Liwag, M.D. (2005). Rozumienie emocji w teorii oceny - implikacje dla rozwoju i uczenia się. Za: M. Lewis, J.M. Haviland-Jones (red.), Psychologia emocji. Gdańsk: Gdańskie Wydawnictwo Psychologiczne.

Stępień, R., Wroński, R.W. (1999). Edukacja obronna młodzieży na przełomie wieków. Kraków: Wydawnictwo Naukowe Wyższej Szkoły Pedagogicznej.

Welsch, W. (1997). Nasza postmodernistyczna moderna. Warszawa: Oficyna Naukowa.

Wróblewski, R. (2010). Przedmiot i metoda nauki o bezpieczeństwie narodowym. Za: P. Sienkiewicz (red.), Metodologia badań bezpieczeństwa narodowego. Materiaty z konferencji naukowej. Warszawa: AON.

Zduniak, A., Kryłowicz, M. (2004). Edukacja dla bezpieczeństwa w rodzinie, szkole i pracy. Warszawa-Poznań: Elipsa.

Zajas, S. (2010). Nauki wojskowe a nauki o bezpieczeństwie i obronności. Za: P. Sienkiewicz (red.), Metodologia badań bezpieczeństwa narodowego Materiaty z konferencji naukowej. Warszawa: AON.

Zalewski, Z. (1991). Psychologia zachowań celowych. Warszawa: PWN.

Żegnałek, K. (2005). Dydaktyka edukacji obronnej. Toruń: Wydawnictwo Adam Marszałek. 